\title{
REVIEW
}

\section{Exposure to carbon monoxide and nitrogen dioxide in enclosed ice arenas}

\author{
T W Pelham, L E Holt, M A Moss
}

Occup Environ Med 2002;59:224-233

This article summarises the latest information on the adverse cardiorespiratory effects of exposure to carbon monoxide $(\mathrm{CO})$ and nitrogen dioxide $\left(\mathrm{NO}_{2}\right)$ in enclosed ice rinks. Sources of $\mathrm{CO}$ and $\mathrm{NO}_{2}$ emissions are identified, current standards for these agents, as well as methods of controlling the emissions, dispersion, and evacuation of these toxic gases are presented. A detailed literature search involving 72 references in English and French from research conducted in North America and Europe was used. Material was from peer reviewed journals and other appropriate sources. Air pollutants such as carbon monoxide (CO), and nitrogen dioxide $\left(\mathrm{NO}_{2}\right)$ which are present in enclosed skating facilities, may exacerbate a pre-existing pathogenic condition in those people who spend considerable time in these environments. Considering the popularity of ice hockey, short track speed skating, and figure skating, and the hundreds of hours that a sensitive person may spend each year in these environments, it would seem appropriate to seek more definitive answers to this important health problem. From the findings and conclusions of the research reviewed in this paper, 10 recommendations are listed.

See end of article for authors' affiliations

Correspondence to:

Professor L E Holt, School

of Health and Human

Performance, Dalhousie

University, Halifax, Nova

Scotia, Canada B3H 3J5;

HOLT@IS.DAL.CA

Accepted

17 October 2001
$\mathrm{O}$ ver the past 30 years, there have been several documented cases of acute carbon monoxide ( $\mathrm{CO}$ ) and nitrogen dioxide $\left(\mathrm{NO}_{2}\right)$ poisoning in Canada and the United States ${ }^{1-12}$ resulting from the release of pollutants into enclosed ice skating arenas during routine ice resurfacing. Studies from North America and Europe have documented ambient conditions that exist inside ice skating arenas. ${ }^{13-33}$ High concentrations of pollutants have also been found in the blood of hockey players and workers in these facilities in controlled experimentation..$^{1827} 283 \mathrm{In}$ Europe, $\mathrm{NO}_{2}$ poisoning has also been shown to occur from emissions of internal combustion ice resurfacing equipment. ${ }^{9}$ An international study ${ }^{15}$ involving 332 rinks located in nine countries found $40 \%$ of the sampled rinks with excess concentrations of $\mathrm{NO}_{2}$.

In North America, the States of Massachusetts, ${ }^{34}$ Minnesota, ${ }^{35}$ and Rhode Island ${ }^{36}$ have enacted guidelines and air quality standards for arenas. Elsewhere, despite heightened awareness, the problem remains. ${ }^{37}$
As many health professionals are called upon to attend people with cardiorespiratory problems, and as there has been an alarming increase in the number and severity of problems among people exercising in these enclosed environments, as evident by the number of recent poisoning incidents, ${ }^{1-12}$ the following information may be of some importance. The goal of this paper is to present the current state of knowledge about exposure to $\mathrm{CO}$ and $\mathrm{NO}_{2}$ in enclosed ice skating rinks, and the adverse health effects of that exposure.

\section{REVIEW OF LITERATURE}

A summary of various epidemiological, environmental, and clinical investigations involving the adverse health effects of poor air quality in enclosed ice rinks on patrons and employees is presented in table 1.

The investigations presented in table 1 have several common findings. Firstly, most studies involved environmental testing after a poisoning incident. Secondly, the environmental investigations identified the emission of $\mathrm{CO}$ and $\mathrm{NO}_{2}$ in the exhaust of the ice resurfacer as the major contributor of ambient pollution in the enclosed ice arena. Thirdly, high concentrations of $\mathrm{CO}$ and $\mathrm{NO}_{2}$ remained in the rink due to poor natural ventilation and inadequate or malfunctioning mechanical ventilation.

Reduction strategies that were highlighted included:

(1) Regular maintenance of ice resurfacing machines.

(2) Installation of pollution control devicesfor example, install catalytic convertor.

(3) Adequate ventilation.

(4) Replace fossil fueled ice resurfacing machine with electric machines.

(5) Introduction of standards and regular monitoring of the ambient conditions of the enclosed ice rink.

Many of the authors of the studies in table 1 expressed concern that exposure to high concentrations of $\mathrm{CO}$ and $\mathrm{NO}_{2}$, particularly among children during exercise, can lead to acute and chronic illness. This topic will be be discussed in more detail later. Also, the limits of concentration of $\mathrm{CO}$ and $\mathrm{NO}_{2}$ proposed for work environments and in arenas, control of the emissions of toxic gas, dispersion and evacuation of toxic gases,

Abbreviations: $\mathrm{Hb}$, haemoglobin; $\mathrm{COHb}$, carboxyhaemoglobin; CHD, cardiovascular heart disease 


\begin{tabular}{|c|c|c|c|c|c|c|}
\hline $\begin{array}{l}\text { Study } \\
\text { (ref No) }\end{array}$ & Type of study & $\begin{array}{l}\text { Identified risk } \\
\text { factors }\end{array}$ & Key health effects or attack rate & $\begin{array}{l}\text { Biomonitoring } \mathrm{CO}, \mathrm{NO}_{2} \\
\text { and key findings }\end{array}$ & Author recommendations & Follow up \\
\hline 1 & Enl or Epl & MIR, IV & COP & Range: $25-50 \mathrm{ppm}$ CO & $\downarrow$ Standards for indoor air quality & ? \\
\hline 2 & Enl or Epl & $g \mid R$ and $p \mid R$ & $\mathrm{COP}$ & After incident 100 ppm CO & $\begin{array}{l}\text { Adjust air fuel mixture, } \\
\text { Warm up gIR and plR, } \\
\text { Shorten resurfacings, } \\
\downarrow \text { No of resurfacings }\end{array}$ & $?$ \\
\hline 3 & Enl or medical reports & MIR, IV & ARI & 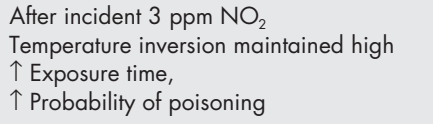 & $\begin{array}{l}\text { Long exhaust pipe, } \\
\text { RMIR, ICM, AV }\end{array}$ & ? \\
\hline 4 & Enl/Epl & MIR, IV & ARI 69\%, Haem 20\% & After incident 3-4 ppm NO & Routine monitoring & $?$ \\
\hline 5 & Enl or clinical investigation & MIR, IV & $\begin{array}{l}\text { COP } \\
\text { Rink employees }\end{array}$ & After incident 100 ppm CO & $\begin{array}{l}\text { RMIR, AV, ReIR, } \\
\text { After warning signs, } \\
\text { Routine monitoring, } \\
\downarrow \text { Standards for indoor air quality }\end{array}$ & $\begin{array}{l}\text { After AV } 23 \text { ppm CO } \\
\text { After RelR } 1 \text { ppm CO }\end{array}$ \\
\hline 6 & Enl or Epl & MIR & COP & After incident 100 ppm CO & $\begin{array}{l}\text { AV, RMIR } \\
\text { QT }\end{array}$ & After ICM, RMIR 5-10 ppm CO \\
\hline 7 & Enl or clinical investigation & MIR, IV & ARI & After incident $4 \mathrm{ppm} \mathrm{NO}{ }_{2}$ & $?$ & $?$ \\
\hline 8 & Enl or Epl & MIR, IV & $\begin{array}{l}\text { COP, Team A } 100 \% \text {, } \\
\text { Team B } 83 \% \\
\text { Medical personnel 100\% } \\
\text { Referees 50\% }\end{array}$ & After incident $47 \mathrm{ppm} \mathrm{CO}$ & AV & ? \\
\hline 9 & Enl or Epl & MpIR, IV & ARI $55.6 \%$ & $\begin{array}{l}\text { After incident } 1250 \mathrm{ppb} \mathrm{NO}_{2} \\
\uparrow \text { Risk of pulmonary symptoms with } \uparrow \text { time } \\
\text { on ice }\end{array}$ & $\begin{array}{l}\text { AV, RelR, } \\
\text { Routine monitoring } \\
\text { Set guidelines for air quality }\end{array}$ & ? \\
\hline 10 & Enl or Epl & MIR, IV & $\begin{array}{l}\mathrm{NO}_{2} \text { induced severe symptoms } 82 \% \text {, } \\
\text { Mild symptoms } 100 \%\end{array}$ & After incident range: $0.5-1 \mathrm{ppm} \mathrm{N \textrm {NO } _ { 2 }}$ & AV, RelR, RMIR & ? \\
\hline 11 & Enl or Epl & MIR, IV & $\begin{array}{l}\text { COP } 54 \% \text { players, } \\
\text { Coaches, teachers }\end{array}$ & After incident 40 ppm CO & ? & ? \\
\hline 12 & Enl or clinical investigation & MIR, IV & $\begin{array}{l}\text { ARI } 48 \% \text { players } \\
\text { Spectators }\end{array}$ & $\begin{array}{l}\text { After incident } 150 \mathrm{ppm} \mathrm{CO} \\
\text { After incident } 1.5 \mathrm{ppm} \mathrm{NO}\end{array}$ & $\begin{array}{l}\text { AV, RelR, RMIR } \\
\text { Education of staff }\end{array}$ & $?$ \\
\hline 13 & Enl 20 rinks & MIR, IV & ? & $\begin{array}{l}73 \mathrm{ppm} \mathrm{CO} \\
0.1 \mathrm{ppm} \mathrm{NO}_{2} \\
\uparrow \mathrm{No} \text { of resurfacings } \\
\uparrow \mathrm{CO} \\
\text { Rinks varied in } \mathrm{CO}\end{array}$ & RMIR, RelR, AV & ? \\
\hline
\end{tabular}




\begin{tabular}{|c|c|c|c|c|c|c|}
\hline $\begin{array}{l}\text { Study } \\
\text { (ref No) }\end{array}$ & Type of study & $\begin{array}{l}\text { Identified risk } \\
\text { factors }\end{array}$ & Key health effects or attack rate & $\begin{array}{l}\text { Biomonitoring } \mathrm{CO}, \mathrm{NO}_{2}, \\
\text { and key findings }\end{array}$ & Author recommendations & Follow up \\
\hline 14 & Enl & MIR, IV & $?$ & $\begin{array}{l}4240 \text { ppb } \mathrm{NO}_{2} \\
1 \text { hour maximal } \\
\text { Increased } \mathrm{NO}_{2}\end{array}$ & Lower $\mathrm{NO}_{2}$ & ? \\
\hline 15 & Enl 332 rinks & MIR, IV & $?$ & $40 \%$ rinks $\uparrow \mathrm{NO}_{2}$ & RelR & $?$ \\
\hline 16 & Enl 70 rinks & MIR & $?$ & $\begin{array}{l}\text { Indoor } \mathrm{NO}_{2} 10 \times \text { v outdoor } \\
60 \% \text { Exceeded standards } \\
1 \text { hour standard } \\
40 \% \text { Exceeded standards } \\
1 \text { week average standard } \\
1 \text { week average } 180 \mathrm{ppb} \mathrm{NO}{ }_{2}\end{array}$ & $\begin{array}{l}\text { Long exhaust pipe } \\
\text { AV, } \\
\downarrow \text { No of resurfacings }\end{array}$ & $?$ \\
\hline 17 & Enl 70 rinks & MIR & $?$ & $\begin{array}{l}\text { Outdoor rink }=16.3 \mathrm{ppb} \mathrm{NO} \\
\text { Indoor rink }=169.5 \mathrm{ppb} \mathrm{NO} \\
\text { Indoor } \mathrm{NO}_{2} 10 \times \text { voutdoor } \\
\mathrm{NO}_{2} \text { higher in rinks with IV }\end{array}$ & $\begin{array}{l}\text { Set guidelines for air quality } \\
\text { AV, RelR }\end{array}$ & $?$ \\
\hline 18 & Enl or clinical investigation & MIR, IV & $\begin{array}{l}\uparrow \mathrm{COHb} \\
\text { Rink employees }\end{array}$ & Range: $55-65$ ppm CO & $\begin{array}{l}\text { RMIR, QT } \\
\text { Fresh air supply to inside rink } \\
\text { Direct exhaust link from garage to outside }\end{array}$ & $?$ \\
\hline 19 & Enl seven rinks & MIR, IV & $?$ & $\begin{array}{l}\text { Range: } 3-57 \mathrm{ppm} \text { CO } \\
\text { Ventilation system not in operation during } \\
\text { resurfacings }\end{array}$ & $\begin{array}{l}\text { Shorten resurfacings, } \\
\text { AV, RelR, RMIR } \\
\text { Routine monitoring }\end{array}$ & $?$ \\
\hline 20 & Enl or Epl & MIR & $?$ & $\begin{array}{l}50 \% \text { of rinks exceeded } 25 \mathrm{ppm} \mathrm{CO} \text {, } \\
\text { Range: } 25-206 \mathrm{ppm} \mathrm{CO}, \\
\text { Ventilation system not in operation during } \\
\text { resurfacings }\end{array}$ & $\begin{array}{l}\text { Routine monitoring } \\
\text { QT, AV }\end{array}$ & $?$ \\
\hline 21 & Enl six rinks & gIR and pIR, IV & $?$ & $\begin{array}{l}\text { gIR range: } 157-304 \mathrm{ppm} \mathrm{CO} \\
\text { plR range: } 75-175 \mathrm{ppm} \mathrm{CO}\end{array}$ & ICM, AV, ReIR & $\begin{array}{l}\text { After ICM } \\
\text { gIR range: } 4-110 \mathrm{ppm} \text { CO } \\
\text { plR range: } 0-105 \mathrm{ppm} \text { CO }\end{array}$ \\
\hline 22 & Epl & Tobacco smoke & $?$ & $\begin{array}{l}1110-1700 \mathrm{ppm} \mathrm{CO}_{2} \\
237 \mathrm{ppb} \mathrm{NO}_{2}\end{array}$ & $?$ & $?$ \\
\hline 23 & Enl or clinical investigation & MIR & ARI & Increased $\mathrm{NO}_{2}$ & Corticosteroid treatment & Condition improved \\
\hline 24 & Enl four rinks & MIR, IV & $?$ & $\begin{array}{l}\text { Range: } 5-110 \text { ppm CO } \\
22.5 \text { ppm caused various } \mathrm{CO} \text { symptoms }\end{array}$ & $\begin{array}{l}\text { AV, RelR, ICM, RMIR, } \\
\text { Warm up machine, } \\
\text { Shorten resurfacings, } \\
\text { Open doors of rink, } \\
\text { During resurfacings, QT, } \\
\text { Routine monitoring }\end{array}$ & $?$ \\
\hline 25 & Enl six rinks & MIR & $?$ & $\begin{array}{l}\text { Range: } 4-117 \mathrm{ppm} \mathrm{CO} \\
\text { Range: } 342-2729 \mathrm{ppb} \mathrm{NO}_{2} \\
\text { Outdoor }=37 \mathrm{ppb} \mathrm{NO}\end{array}$ & $\begin{array}{l}1 \text { hour maximal } \\
\text { Allowable } 20 \mathrm{ppm} \mathrm{CO} \text { and } 25 \mathrm{ppb} \mathrm{NO}{ }_{2}\end{array}$ & $?$ \\
\hline
\end{tabular}




\begin{tabular}{|c|c|c|c|c|c|c|}
\hline $\begin{array}{l}\text { Study } \\
\text { (ref No) }\end{array}$ & Type of study & $\begin{array}{l}\text { Identified risk } \\
\text { factors }\end{array}$ & Key health effects or attack rate & $\begin{array}{l}\text { Biomonitoring } \mathrm{CO}, \mathrm{NO}_{2} \\
\text { and key findings }\end{array}$ & Author recommendations & Follow up \\
\hline 26 & Enl & MIR & ? & $\begin{array}{l}1 \text { week average } \\
\text { plR: } 206 \mathrm{ppb} \mathrm{NO} \\
\text { gIR: } 132 \mathrm{ppb} \mathrm{NO}{ }_{2} \\
\text { elR: } 37 \mathrm{ppb} \mathrm{NO}_{2}\end{array}$ & $\begin{array}{l}\text { AV, RelR, } \\
\text { ICM, RMIR } \\
\text { Routine monitoring }\end{array}$ & $\begin{array}{l}\text { Engineering controls: } \mathrm{AV} \downarrow \mathrm{NO}_{2} \\
65 \%\end{array}$ \\
\hline 27 & Exposure-absoption & $?$ & $?$ & Linear exposure-absoption relation & $\downarrow \mathrm{CO}$ in rinks & $?$ \\
\hline 28 & Exposure-absoption 10 rinks & MIR & $?$ & $\begin{array}{l}\text { Range: } 1.6-131.5 \mathrm{ppm} \mathrm{CO} \\
\uparrow 10 \mathrm{ppm} \mathrm{CO}=\uparrow \mathrm{COHb} 1 \%\end{array}$ & $\begin{array}{l}\mathrm{CO} \text { standard of } 20 \mathrm{ppm} \text { for } 90 \text { minutes in } \\
\text { rinks }\end{array}$ & $?$ \\
\hline 29 & Enl & MIR, IV & $?$ & Increased CO & $\begin{array}{l}\text { AV, long exhaust pipe } \\
\text { RMIR, ICM, QT } \\
\text { Open doors of rink during resurfacings, } \\
\text { Warm up machine, } \\
\text { Flexible exhaust hose with direct link to } \\
\text { outside }\end{array}$ & $?$ \\
\hline 30 & Enl & MIR & $?$ & $\begin{array}{l}1 \text { hour average } \\
17-29 \text { ppm } \mathrm{CO} \\
0.14-3.96 \mathrm{ppm} \mathrm{NO}\end{array}$ & $\begin{array}{l}\uparrow \mathrm{CO} \text { glR } \\
\uparrow \mathrm{NO}_{2} \text { plR }\end{array}$ & ? \\
\hline 31 & Enl & MIR & $?$ & 23\% Exceeded standards & Enforce regulations & ? \\
\hline 32 & Enl & MIR, IV & $?$ & Range: $50-100$ ppm CO & Routine monitoring & After RMIR, AV 2-3 ppm CO \\
\hline 33 & Enl or Epl six rinks & MIR, IV & $5 \times \mathrm{COHb}$ & $\begin{array}{l}\text { 82\% Exceeded standards } \\
\text { Range: } 23-90 \text { ppm CO }\end{array}$ & RMIR, AV, RelR & ? \\
\hline
\end{tabular}




\begin{tabular}{|c|c|c|c|}
\hline Year & Province or state & $\begin{array}{l}\text { Total arenas } \\
\text { tested (n) }\end{array}$ & $\begin{array}{l}\text { Arenas with air } \\
\text { contamination (n) }\end{array}$ \\
\hline 1971 & Minnesota & 18 & 13 \\
\hline 1976 & Quebec & 16 & 13 \\
\hline 1978 & Massachusetts & 8 & 6 \\
\hline 1980 & Ontario & 4 & 1 \\
\hline 1984 & British Columbia & 64 & 32 \\
\hline 1989 & Quebec & 10 & 3 \\
\hline 1989 & Quebec & 45 & 23 \\
\hline
\end{tabular}

method of measuring ambient $\mathrm{CO}$ and $\mathrm{NO}_{2}$, and recommendations relative to ventilation will be discussed.

\section{CONTAMINANTS}

Many noxious compounds are produced within enclosed ice arenas. These include various oxides of carbon, oxides of nitrogen, aldehydes, particulate matter in a wide range of sizes, and various highly toxic volatile organic compounds. Point sources of these agents include standard resurfacing equipment, food preparation equipment—for example, deep fryers of the rink's restaurant-refrigeration units, and smoking among patrons. However, this paper will focus on the two contaminants most often cited as the prime sources of cardiorespiratory distress, $\mathrm{CO}$ and $\mathrm{NO}_{2}$.

It can be seen from table 1 that $\mathrm{CO}$ is the gas most often cited in academic reports and the media as responsible for intoxication in ice skating arenas. Several

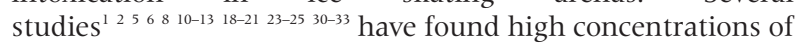
$\mathrm{CO}$ to be common in many enclosed ice skating arenas (table 2).

Carbon monoxide is a colourless, odourless gas, which combines with haemoglobin $(\mathrm{Hb})$ in the blood to form carboxyhaemoglobin $(\mathrm{COHb})$. Haemoglobin has an affinity 240 times higher for $\mathrm{CO}$ than for oxygen. ${ }^{38}$ There is a positive linear relation between environmental concentrations of $\mathrm{CO}$ and alveolar absorption of $\mathrm{CO}^{27}{ }^{28} \mathrm{As} \mathrm{Hb}$ is normally responsible for the transport of oxygen, the presence of $\mathrm{CO}$ in inhaled air gradually results in hypoxia. ${ }^{38}$ The mechanics of this process have been explained.

Increased CO uptake shifts the oxyhaemoglobin dissociation curve to the left and oxygen tension is reduced. ${ }^{39}$ In response, ventilation rate will increase. The increase in ventilation results in a larger amount of inhaled $\mathrm{CO} \%$ in the alveoli. More CO is absorbed into the blood, and CO toxicity becomes more pronounced. This cycle will continue to a point where the victim cannot function.

The brain, heart, and exercising skeletal muscles tend to be the most sensitive targets for $\mathrm{CO}^{38}$ Clinical reports and controlled experimentation have shown that a particular group of symptoms are associated with specific concentrations of $\mathrm{COHb}$ (table 3). At low concentrations of $\mathrm{COHb}$, vision is altered and the arteries dilate. Nausea, headaches, and disorientation occur at higher concentrations. Very high concentrations can be life threatening. ${ }^{39}$

Uptake of CO during exercise has been shown to be three to four times greater than at rest. ${ }^{40}$ The exposure-absorption studies of Lévesque $e a^{l^{27}}{ }^{28}$ and Spengler $e t a l^{33}$ found a linear relation between percentage saturation of $\mathrm{COHb}$ in hockey players and exposure time and concentrations of CO. Lévesque et $\mathrm{al}^{27}{ }^{28}$ have shown that for each 10 parts per million (ppm) of $\mathrm{CO}$ in an arena, an adult male hockey player, during a 1.5 hour game of hockey, will have a COHb increase of $1.0 \%$. Spengler et $\mathrm{al}^{33}$ found that a mean environmental concentration of 22.5 ppm CO is sufficient to raise the average $\mathrm{COHb}$ concentration in hockey players from $1.1 \%$ to $3.2 \%{ }^{24}$ This concentration has been exceeded by most arenas tested in various studies. $^{26714242931}$ Several studies have suggested that high risk people (children, elderly people, people with cardiovascular inefficiencies, or pregnant women) were more susceptible to increased concentrations of $\mathrm{COHb}$ while participating in or observing activities in enclosed rinks. ${ }^{5} 132427283133$

As well as the acute adverse health effects of CO poisoning, research has suggested that long term exposure to $\mathrm{CO}$ can increase the risk of cardiovascular heart disease (CHD).$^{24}$ For people who have CHD, exposure to increased concentrations of $\mathrm{COHb}$ can lead to myocardial ischaemia, abnormal cardiac rhythms or arrhythmias, or in severe cases, myocardial infarction. ${ }^{41-43}$

During exercise, venous oxygen tension has been shown to decrease with exposure to $\mathrm{CO}$, leading to an increase in heart rate, cardiac output, and coronary artery flow. ${ }^{44}$ People with CHD are already compromised by the limited circulatory capacity of the coronary system, further predisposing them to exercise induced angina. ${ }^{45}$

Along with the adverse effects placed on the cardiorespiratory system, low level exposure to $\mathrm{CO}$ has been associated with impaired neuropsychological function. ${ }^{46}$ Attention span, memory, cognitive planning, and information processing have been shown to be jeopardised. In cases of CO poisoning, neuropathological hippocampal changes and diffuse cortical atrophy have been found with magnetic resonance imaging. ${ }^{47}$

Carbon monoxide is a byproduct of the incomplete combustion of the organic fuels used by the internal combustion engine of the ice resurfacer. Even a well tuned gasoline or propane driven internal combustion engine will produce a certain quantity of $\mathrm{CO}^{13} 30$

These emissions can be amplified by reductions in the air/fuel relation. ${ }^{13}$ In an environmental investigation, Johnson et al. ${ }^{11}$ found $115 \mathrm{ppm}$ of $\mathrm{CO}$ in the exhaust of a gasoline powered ice resurfacer after the addition of a catalytic convertor. The findings of the studies presented in table 1 are suggestive that an interaction between the adverse health effects on

\begin{tabular}{ll}
$\begin{array}{l}\text { Table } 3 \\
\mathrm{COHb}{ }^{37}\end{array}$ & Symptoms associated with the absorption of \\
\hline $\begin{array}{l}\text { COHb } \\
\text { concentration }\end{array}$ & Effects \\
\hline $0.0 \%-2.5 \%$ & No apparent symptoms \\
$2.5 \%-5.0 \%$ & $\begin{array}{l}\text { Altered vision } \\
\text { Arterial dilation } \\
\text { Reduced attention span particularly while driving an } \\
\text { automobile }\end{array}$ \\
$5.0 \%-10 \%$ & $\begin{array}{l}\text { Altered brightness sensitivity } \\
\text { Unusual increase in strained breathlessness } \\
\text { Distortion of fine manual dexterity }\end{array}$ \\
$20 \%-30 \%$ & $\begin{array}{l}\text { Headaches } \\
\text { Start of nausea }\end{array}$ \\
Coordination problems \\
$30 \%-40 \%$ & $\begin{array}{l}\text { Severe headaches } \\
\text { Dizziness }\end{array}$ \\
& $\begin{array}{l}\text { Nausea and vomiting } \\
\text { Judgement alteration }\end{array}$ \\
$50 \%-50 \%$ & $\begin{array}{l}\text { Aggravation of the same symptoms } \\
\text { Confusion }\end{array}$ \\
$50 \%-60 \%$ & $\begin{array}{l}\text { Loss of consciousness } \\
\text { Convulsions } \\
\text { Coma } \\
\text { Respiratory arrest } \\
\text { Death }\end{array}$ \\
\hline
\end{tabular}




\begin{tabular}{|c|c|c|c|}
\hline \multicolumn{4}{|c|}{$\begin{array}{l}\text { Table } 4 \text { Limits of concentration of gas proposed in work environments and in } \\
\text { arenas }^{37}\end{array}$} \\
\hline & \multicolumn{2}{|c|}{$\mathrm{CO}$ (ppm) } & \multirow{2}{*}{$\begin{aligned} & \mathrm{NO}_{2} \\
&-(\mathrm{ppm}) \\
& 8 \mathrm{~h}\end{aligned}$} \\
\hline & $1 \mathrm{~h}$ & $8 \mathrm{~h}$ & \\
\hline \multicolumn{4}{|l|}{ Work environment: } \\
\hline American Conference of Government Hygienists ${ }^{56}$ & - & 50 & 3 \\
\hline Building Code of Québec ${ }^{37}$ & 400 & 50 & 3 \\
\hline Oatman and Zetterlund ${ }^{31}$ & 200 & 35 & 5 \\
\hline \multicolumn{4}{|l|}{ Arenas: } \\
\hline $\begin{array}{l}\text { Luckhurst and French (Department of Health and Social Development, Winnipeg, } \\
\text { Manitoba) }\end{array}$ & 25 & 12 & - \\
\hline MHPC, Québec ${ }^{37}$ & 30 & 13 & - \\
\hline Kwok, (Community Health Dept., Etobicoke, Ontario) ${ }^{24}$ & 25 & 13 & - \\
\hline Ontario Arenas Association ${ }^{57}$ & 35 & - & - \\
\hline King County Health Department, Seattle, Washington ${ }^{21}$ & 25 & - & - \\
\hline British Columbia Ministry of Labor ${ }^{58}$ & 25 & - & - \\
\hline Lévesque et al, DSC, CHUL, Québec 2728 & 20 & - & - \\
\hline Coueffin, Simon Fraser Health Unit, British Columbia ${ }^{58}$ & 25 & 12 & - \\
\hline Minnesota Department of Health ${ }^{35}$ & - & - & 0.5 \\
\hline National primary ambient air quality standards ${ }^{59}$ & 13 & 9 & 0.14 \\
\hline DSC and of Québec ${ }^{37}$ & 20 & - & 0.5 \\
\hline
\end{tabular}

employees and patrons of enclosed ice arenas and high ambient concentrations of $\mathrm{CO}$ from the emissions of engines of the ice resurfacer does exist.

Illness associated with CO poisoning is probably greatly underreported. ${ }^{32}{ }^{36}$ This may be due to the fact that the symptoms of $\mathrm{CO}$ poisoning are non-specific and may incorrectly be attributed to other causes.

The internal combustion engine of a resurfacer can also produce another gas, $\mathrm{NO}_{2}$. Although cases of $\mathrm{NO}_{2}$ intoxication seem less frequent or have been rarely documented it is important to recognise the symptoms. Low concentrations of $\mathrm{NO}_{2}$ may irritate the mucous membrane of the respiratory passageways, ranging from irritation of the respiratory tract, up to acute pulmonary oedema. ${ }^{47}$ The biochemical mechanism suggested for such insults to the respiratory tract is that $\mathrm{NO}_{2}$ combines with water in the lungs producing nitrous and nitric acid.

One of the most cited incidents of $\mathrm{NO}_{2}$ poisoning occurred in Minnesota, when 116 people attending two hockey games reported various symptoms ranging from cough (97\%) to haemoptysis (35\%). Hedbery et al $l^{4}$ found $89 \%$ of the young hockey players with asthma reported more severe symptoms after exposure. In other cases, Morgan ${ }^{7}$ and Karlson-Stilber et al ${ }^{23}$ have documented pulmonary oedema in young hockey players after exposure to low concentrations of $\mathrm{NO}_{2}$ during a hockey game. In these incidents, a malfunctioning ice resurfacer was the source of $\mathrm{NO}_{2}$, and high concentrations remained in these rinks due to inadequate ventilation systems.

Although the factors responsible for asthma may vary among children, recent research has suggested that high concentrations of $\mathrm{NO}_{2}$ in the enclosed ice skating arena may be associated with significantly higher percentages of asthma among young participants. ${ }^{48-50}$ On the other hand, research has suggested that particular modes of exercise and sporting activities alone have the potential to bring about adverse effects in some children with asthma. ${ }^{5152}$

It has been suggested that low intensity, long duration activities are more likely to elicit airway obstruction than high intensity, short duration activities. ${ }^{51}$ A bronchoconstriction/ bronchospasm event has been identified to be more likely in such outdoor sporting activities as cross country skiing. ${ }^{52}$ This sport is usually performed in cold, dry air. Although some of the risk factors inherent in our indoor sport environments have been identified, the specific effects on the athletes and others in the environment needs much more study. The dearth of scientific studies seems surprising in the light of the wide- spread use of indoor fitness and recreation facilities for organised youth sports.

In respiratory research, attempts have been made to identify high risk environments for people with asthma. One line of research has focused on the indoor living environment of asthmatic people. ${ }^{53}{ }^{54}$ However, another indoor environment with the potential for triggering asthmatic symptoms, and therefore placing the person with asthma at high risk, is the indoor skating rink. Pelham $e t a l^{55}$ found a significant decrease in lung function values in children with asthma after activity in an enclosed ice rink versus activity in a well ventilated gymnasium and a swimming pool.

As already mentioned, children, in particular those with asthma, are at a higher risk of poisoning from ambient pollutants than adults while partaking in activities in enclosed rinks. This is evident with $\mathrm{NO}_{2}$, which is heavier than most constituents of air, and would migrate towards the ice. In the confined space of the ice surface, with the lack of circulation due to inadequate ventilation, a temperature inversion condition would exist, trapping $\mathrm{NO}_{2}$. The $\mathrm{NO}_{2}$ concentrations would build in the lower breathing zone of the child, but much less so in that of an adult.

The concentration of the pollutant in ambient air has the potential to be an important feature in determining level of risk. As already mentioned, the most likely source of air pollutants in the enclosed ice skating rink is the internal combustion engine of the resurfacer. Several studies 379121617 hypothesised bronchoprovocation by high concentrations of irritants, particularly, $\mathrm{NO}_{2}$.

\section{STANDARDS}

Standards have been applied for air quality in work environments. In these environments, the CO concentration may fluctuate, but the time weighted average (TWA) for an 8 hour exposure should not exceed 25 ppm. ${ }^{56}$

Several studies presented in table 1 recommend the establishment and enforcement of standards specific for enclosed ice skating rinks. ${ }^{21}{ }^{24} 27-29$ It has been recommended that the average concentrations of $\mathrm{CO}$ and $\mathrm{NO}_{2}$ in arenas be lower than those required in the work environment. Table 4 shows some of the proposed limits for $\mathrm{CO}$ and $\mathrm{NO}_{2}$, as summarised in the guidelines and recommendations for environmental safety in sporting facilities published by the Régie de la sécurité dans les sports du Québec. ${ }^{37}$ It is important for health professionals, who may ultimately be responsible for 
Table 5 Control of $\mathrm{CO}$ and $\mathrm{NO}_{2}$ emissions from the resurfacer ${ }^{37}$

\begin{tabular}{|c|c|}
\hline Means & Comments \\
\hline Regular testing of $\mathrm{CO}$ & $\begin{array}{l}\text { The rate of } \mathrm{CO} \text { must be less than } 0.5 \% \text { for resurfacers driven by propane and exhaust pipes less than } \\
1.0 \% \text { for those driven by gasoline } \\
\text { Testing includes samples*; } \\
\text { Idling test after } 3 \text { minutes } \\
\text { High rate test after } 5 \text { minutes } \\
\text { The probable cause of an excessive quantity of } \mathrm{CO} \text {; } \\
\text { At idle, is a choke problem } \\
\text { At a high rate, is an undersupply of air }\end{array}$ \\
\hline $\begin{array}{l}\text { Permanent installation of an apparatus to } \\
\text { measure the concentration of gas* }\end{array}$ & $\begin{array}{l}\text { Capable of immediately detecting of all abnormal concentrations of toxic gas at the opening of the } \\
\text { exhaust pipe } \\
\text { The installation of a warning light or of a buzzer on the instrument panel that will warn the employee of } \\
\text { a malfunction }\end{array}$ \\
\hline Regular maintenance of the motor* & $\begin{array}{l}\text { General inspection and tune up of the motor every } 6 \text { motor weeks or for every } 50 \text { hours of use } \\
\text { Inspection of contaminant emission } \\
\text { Carburettor adjustment } \\
\text { Carburettor cleaning } \\
\text { Inspection of the air filter } \\
\text { Inspection of the throttle }\end{array}$ \\
\hline Motor equipped with a catalytic purifier & $\begin{array}{l}\text { The purifier can reduce the emissions of } \mathrm{CO} \text { and non-burned hydrocarbons by up to } 95 \% \text {. The catalytic } \\
\text { purifier functions adequately when it is heated up ( } 5 \text { to } 7 \text { minutes) }\end{array}$ \\
\hline Operate with an optimal air/carbon mixture & $\begin{array}{l}\text { Especially for gas resurfacers. } \\
\text { A mixture too rich (reduction of air/carbon relation) produces an excessive quantity of } \mathrm{NO}_{2}\end{array}$ \\
\hline $\begin{array}{l}\text { Qualified personnel to operate the resurfacer* } \\
\text { Frequency of resurfacing* }\end{array}$ & $\begin{array}{l}\text { An experienced employee can reduce the working time of the surfacer to a minimumin } \\
\text { Avoid if possible the surfacing between each period } \\
\text { Space out the use to } 90 \text { minutes instead of } 60 \text { minutes }\end{array}$ \\
\hline
\end{tabular}

the safety of athletes in these environments, to become familiar with these values and the pathological consequences of high concentrations of these pollutants.

However, in consideration of the sustained and vigorous physical effort (three or more times basal metabolic rate), the problem for those training at ice skating sports differs greatly from that of workers in the arena. At the time of skating, the respiratory rate can be 10 times higher than at rest. ${ }^{55}$ Therefore, upon exposure to a similar concentration of $\mathrm{CO}$, the rate of $\mathrm{COHb}$ in the blood will increase much more rapidly in the hockey player, for example, than in the arena employee. ${ }^{27}{ }^{28}$ This is particularly true for children who have a higher metabolic rate than adults. ${ }^{55}$

The following facts, already mentioned, would support a recommendation that the mean concentration of $\mathrm{CO}$ and $\mathrm{NO}_{2}$ in arenas should be below those regulated in a work environment.

(1) For each $10 \mathrm{ppm}$ of CO in an arena, an adult hockey player, on the basis of a 1.5 hour game of hockey, absorbs enough $\mathrm{CO}$ to increase his $\mathrm{COHb}$ concentration by $1.0 \%{ }^{28}$

(2) A threshold of $3 \%$ of COHb in the blood is sufficient to make the early symptoms of poisoning evident. ${ }^{38}$

(3) In general, non-smokers have a $\mathrm{COHb}$ of slightly less than $1 \%{ }^{38}$

Again health professionals must become familiar with these values.

Although the reported cases of $\mathrm{NO}_{2}$ poisoning have been much more rare than CO outbreaks, it should still be considered a potentially serious health hazard. ${ }^{4101617}$ In February 1988, in Québec, nine people showed clinical symptoms suggestive of $\mathrm{NO}_{2}$ poisoning. Air samples indicated the presence of $3 \mathrm{ppm}$ of $\mathrm{NO}_{2}{ }^{3}$

Again, the permissible maximum concentrations for a work environment are not appropriate for a sports environment. In the case of $\mathrm{NO}_{2}$ as in the case for $\mathrm{CO}$, the recommended reference limits for arenas are at least 10 times lower than in the occupational setting. In the State of Minnesota, air quality standards for enclosed ice arenas state that $\mathrm{NO}_{2}$ should not exceed 0.5 ppm for a 1 hour exposure. ${ }^{35}$ However, this criterion for a maximum limit of $\mathrm{NO}_{2}$ in the surrounding air of an arena may be too high.

Controlled exposure studies tend to support an association between low concentrations of $\mathrm{NO}_{2}$ and an increased probability of respiratory distress among asthmatic people. Brauer et al have studied bronchospasm response in asthmatic people after inhalation of $0.3 \mathrm{ppm} \mathrm{NO}$ and exercising in a cold environment. ${ }^{60}$ It has been shown that $0.2 \mathrm{ppm}$ of $\mathrm{NO}_{2}$ produces respiratory symptoms in asthmatic people performing an exercise challenge test in a cold environment. ${ }^{61}$ Indeed, several studies have reported increased reactivity after exposure to $0.10 \mathrm{ppm} \mathrm{NO}_{2}$ in asthmatic people. ${ }^{62-64}$

Finally, the Province of Québec has developed recommendations for monitoring air quality in arenas, with special reference to concentrations of $\mathrm{NO}_{2}$ emitted by the resurfacing machine.$^{37}$ Although exposure to $\mathrm{CO}$ and $\mathrm{NO}_{2}$ in enclosed ice arenas is a serious health hazard, ${ }^{65-70}$ no federal policies currently exist for any contaminants in ice arenas.

Researchers from Sweden ${ }^{914}$ and Finland ${ }^{30}$ have expressed similar health concerns about $\mathrm{NO}_{2}$ exhaust from the resurfacing machine, and have advocated close monitoring of ambient $\mathrm{NO}_{2}$ concentrations. However, North American health professionals have recently advocated the use of electric resurfacing machines as the means of eliminating the pollution problem in enclosed ice rinks. ${ }^{9526}$

\section{CONTROL OF THE EMISSIONS OF TOXIC GAS}

In most cases of poisoning, the source of contamination has been shown to be the ice resurfacer. As mentioned earlier, these machines are driven by an internal combustion motor fuelled by propane, gasoline, or diesel.

The combustion of motor fuel necessarily results in the formation of contaminants. However, the concentration of contaminants is determined by the efficiency of combustion of the motor fuel. ${ }^{132}$ Well kept resurfacers fuelled by propane usually generate less $\mathrm{CO}$ than those fuelled by gasoline. As for $\mathrm{NO}_{2}$, the differences are minimal. ${ }^{1321}$ Finally, resurfacers that use diesel have numerous secondary pollutants (poor odour).

A simple solution would be the purchase of an electric resurfacer. A North American company has introduced a series of these machines for commercial use. However, the cost of one such machine is $60 \%$ higher than that of the internal combustion engine machines.

Nevertheless, the initial difference becomes less important if the costs of fuel and the regular upkeep of the motor are added to the costs of the internal combustion resurfacer. 
Table 6 Dispersion and evacuation of toxic gases ${ }^{37}$

\begin{tabular}{ll}
\hline Means & Comments \\
\hline Initial operation of the resurfacer (evacuation) & $\begin{array}{l}\text { The heating up of the motor is necessary for optimal functioning of the catalytic purifier. This should be } \\
\text { done outside the arena or in a ventilated room and equipped with a flexible hosepipe at least } 4 \mathrm{~m} \\
\text { long attached to the exhaust pipe permitting the transfer of contaminants to the outside } \\
\text { The exhaust pipe must be installed vertically. It must be lengthened to } 2.5 \text { meters ( } 8 \text { feet) above ice } \\
\text { level. The escaping gas can thus be projected outside the temperature inversion zone } \\
\text { The goal of creating openings is during resurfacing to lessen the effect of isolation and to try to } \\
\text { momentarily break the temperature inversion zone. It is nevertheless necessary to prohibit access to the } \\
\text { ice during surfacing } \\
\text { A system should be in constant operation. It must be strong enough to create air movement at ice level } \\
\text { to achieve an exchange between the air at ice level and the surrounding air in the arena } \\
\text { The system should be in constant use when the resurfacer is used often (evening, end of the week, } \\
\text { tournament, etc). At other times, the system must operate for at least } 20 \text { minutes after the resurfacer is } \\
\text { shut off }\end{array}$ \\
Ventilation system (dispersion) &
\end{tabular}

Moreover, the cost of the operation and maintenance of a ventilation system to maintain an acceptable concentration of contaminants is high without taking into account the initial instillation costs. ${ }^{12}$

Among the resurfacers with internal combustion motors, those driven by propane emit the least pollutants. ${ }^{24}$ It is recommended that a gasoline resurfacer should be converted to propane by changing the system of vaporisation and other necessary adjustments. These modification costs are minimal.

Nevertheless, no matter the type of fuel used, regular upkeep of the motor is essential to control the emissions of CO and $\mathrm{NO}_{2}$. Regular verification of emissions of contaminants at the level of the exhaust pipe should be conducted. General guidelines for the control of $\mathrm{CO}$ and $\mathrm{NO}_{2}$ emissions from the resurfacer are shown in table 5 .

Other sources of pollutants may be the heating systemnotably systems driven by gasoline. ${ }^{12}$ These systems must be kept in optimum condition by rigorously following maintenance guides furnished by manufacturers. A general verification and a tune up of these systems every 6 weeks have been recommended. ${ }^{12}$

Finally, it is difficult to evaluate the contribution of cigarette smoke to the quality of the air in arenas without taking into account different dimensional volumes of the arenas. However, the presence of many smokers, particularly during tournaments, can certainly contribute to increasing the concentrations of pollutants.

\section{DISPERSION AND EVACUATION OF TOXIC GASES}

The combination of $\mathrm{CO}$ and $\mathrm{NO}_{2}$ does occur in ice rinks. One question is how to minimise the exposure to such pollutants.

Arenas generally have similar configuration even though their capacities vary greatly. The ice surface is surrounded by a board barrier. In arenas equipped with spectator stands, plexiglas is mounted on the board barrier.

The barrier and plexiglas tend to limit air circulation. At ice level, the temperature is usually near $0^{\circ} \mathrm{C}$. At plexiglas level, the temperature varies very little, but it can reach $5^{\circ} \mathrm{C}$ at the top of the plexiglas, and reach more than $15^{\circ} \mathrm{C}$ at stand level. ${ }^{12}$

This disparity in such a limited area tends to create a temperature inversion zone, trapping pollutants at ice level. Thus, after several resurfacings, the concentrations of $\mathrm{CO}$ and $\mathrm{NO}_{2}$ increase to concentrations that could present a risk to the health of the people exposed, ${ }^{1321}$ particularly for short people, such as young children, working at high metabolic rates.

The evacuation of polluted air and delivery of a supply of fresh air is essential in the maintenance of air quality in arenas. An effective ventilation system is needed for this purpose. Guidelines for the dispersion of pollutants are presented in table 6.

The volume of the arena is the most important factor when designing the ventilation system for the removal of pollutants. Air must be exchanged at least once an hour when the arena is in operation. ${ }^{58}$ An example of guidelines for measuring CO and $\mathrm{NO}_{2}$ has been proposed (table 7).

To assure that pollutant concentrations are below maximum limits, the systems must: $(a)$ be continually working; $(b)$ distribute air adequately to ventilate the entire arena; $(c)$ be in a position to disperse and evacuate toxic gases.

To determine the efficiency of a ventilation system, based on the volume of the building and two samples of $\mathrm{CO}$ or $\mathrm{NO}_{2}$ taken after operation of the resurfacer at 30 minute intervals, it suffices to use the following formula first proposed by Davis and Drenchen ${ }^{19}$ :

$$
\mathrm{Q}=\frac{2.3}{\mathrm{t}} \mathrm{V} \log _{10} \frac{\mathrm{C}}{\mathrm{Co}}
$$

Where: $Q=$ rate of effective ventilation (feet ${ }^{3} /$ minute); $^{2}$ $\mathrm{v}=$ volume of the arena $\left(\right.$ feet $\left.^{3}\right) ; \mathrm{t}=$ interval between the samples (minutes); $\mathrm{C}=$ final concentration of $\mathrm{CO}(\mathrm{ppm})$; and $\mathrm{Co}=$ initial concentration of $\mathrm{CO}(\mathrm{ppm})$.

Table 7 Method of measuring ambient $\mathrm{CO}$ and $\mathrm{NO}_{2}{ }^{37}$

\begin{tabular}{|c|c|}
\hline Characteristic & Comment \\
\hline Observed gases & $\begin{array}{l}\text { Carbon monoxide }(\mathrm{CO}) \\
\text { Nitrogen dioxide }\left(\mathrm{NO}_{2}\right)\end{array}$ \\
\hline Proposed apparatus* & $\begin{array}{l}\text { Manual pump for detection of material required to measure colour within the } \mathrm{CO} \text { sensitivity range } 0-50 \text { ppm } \\
\text { Colour measure tubes for } \mathrm{NO}_{2} \text { sensitivity range between } 0 \text { and } 5 \mathrm{ppm}\end{array}$ \\
\hline Duration of sampling & According to the directions of the manufacturer \\
\hline Time of sampling $\dagger$ & A minimum of once weekly, at a fixed time (hour, day) corresponding to the times of greatest use of the resurfacer \\
\hline
\end{tabular}

*This material as well as the apparatus proposed can be bought in any store selling safety equipment. It is important that the pump and the tubes are of the same material, because they are not interchangeable. The tubes must be stored at a temperature of $0-5^{\circ} \mathrm{C}$ (in the refrigerator).

tAt the time of special activities where there is intensive use of the resurfacer (tournament, reduction in the thickness of the ice, etc). The sampling must be done immediately after the end of the time of resurfacing. To assure a better result, it is recommended that the results be recorded in an ambient air observation register. 
Table 8 Recommendations relative to ventilation ${ }^{37}$

\begin{tabular}{|c|c|}
\hline Sources & Recommendation \\
\hline $\mathrm{Kwok}^{24}$ & $\begin{array}{l}1500 \mathrm{feet}^{3} / \mathrm{min} \text { during the operation of the resurfacer } 5000-7500 \\
\text { feet }^{3} / \mathrm{min} \text { all of the time }\end{array}$ \\
\hline Oatman and Zetterlund ${ }^{31}$ & $\begin{array}{l}1700-2500 \mathrm{feet}^{3} / \mathrm{min} \text { for arenas of } 300000 \\
12000-17500 \mathrm{feet}^{3} / \mathrm{min} \text { for arenas of } 2000000\end{array}$ \\
\hline Davis and Drenchen ${ }^{19}$ & $50000 \mathrm{feet}^{3} / \mathrm{min}$ during the operation of the resurfacer \\
\hline Anderson $^{13}$ & $\begin{array}{l}10000 \mathrm{feet}^{3} / \mathrm{min} \text { when using a propane resurfacer } \\
15000 \mathrm{feet}^{3} / \mathrm{min} \text { when using a gas resurfacer }\end{array}$ \\
\hline American Society of Heating Refrigerating and Air-conditioning Engineers ${ }^{71}$ & $0-15 \mathrm{feet}^{3} / \mathrm{min}$ per person \\
\hline Ontario Recreation Facilities Association ${ }^{57}$ & $300 \mathrm{feet}^{3} / \mathrm{min}$ for each volume 3 of the resurfacer used \\
\hline
\end{tabular}

Sampling procedures are presented in table 8 .

To have an effective arena ventilation system, regular corrective measures (maintenance, cleaning, system modification, etc) must be taken.

\section{CONCLUSIONS AND RECOMMENDATIONS}

In this paper we have focused on two primary agents for eliciting cardiorespiratory distress in ice arenas. However, these pollutants are never isolated and little research has been done on the adverse health effects of various combinations of such noxious agents. The additive and synergistic effects of various mixtures may represent a more serious health hazard than exposure to each pollutant, separately. Research is needed to establish realistic standards for the potential high risk factors of combined concentrations of toxins in sporting and work environments. Research is essential in developing acceptable national standards of $\mathrm{CO}$ and $\mathrm{NO}_{2}$ threshold limits. Criteria for the establishment of acceptable values must take into account the possible interactive nature of these agents with other pollutants. Also, the singular effects of pollutants such as particulates, refrigerants, sulfur dioxide, and volatile organic compounds have not been adequately investigated. There has been only one study which investigated particulates ${ }^{30}$ and one involving volatile organic compounds. ${ }^{23}$ These chemicals are very serious toxins. Even in isolation these irritants have the potential to be a serious health hazard, but in combination they may pose an even greater potential for adverse health effects. Given the concern among health professionals of the incidence of many cardiovascular and respiratory diseases, the possible role of environmental pollutants as potentiators of cardiorespiratory disease $\mathrm{f}^{72}$ merits further investigation.

Although ideally comprehensive and continuous monitoring of several known major toxic contaminants $\left(\mathrm{CO}, \mathrm{NO}_{2}\right.$, aldehydes (acetaldehydes), small particulate matter (aerosol size of $2.5 \mu \mathrm{m}$ ) and various volatile organic compounds, benzene, toluene, $o$-xylene, $m$-xylene, and $p$-xylene ) would be preferred. However, a more practicable approach is needed for the financially restrained, community based ice rink.

The following recommendations are based on the findings and conclusions of the studies in table 1 and the information presented in tables 2-8. These strategies primarily involve either reducing emissions from the ice resurfacing machine, or the evacuation of the emissions from the enclosed ice arena.

(1) Regular and proper installation, adjustments, and operation of ice resurfacing machines by a qualified technician. This would include installation of pollution control devices-for example, install catalytic convertor and a longer exhaust pipe-and mandatory safety inspections.

(2) Installation and continuous operation of an effective mechanical ventilation system. This would include a direct system from the ice surface to the outdoor environment, a direct line from the garage (with a set up for a direct line for the exhaust pipe of the resurfacer) to the outdoor environment, and a fresh air supply to the rink surface.

(3) Open rink doors during and after resurfacings.
(4) Replace the fossil fuelled ice resurfacing machine with an electric machine.

(5) Introduction of standards and regular monitoring of the ambient conditions of the enclosed ice rink (active enforcement of these standards required).

(6) Establish air quality standards: I hour maximal allow-

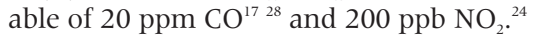

(7) Develop an inexpensive, but effective toxic chemical surveillance programme.

(8) Train and test (certify) operators in effective techniques of reducing the frequency and shortening the duration of resurfacing, and to operate the resurfacer in a manner to minimise emissions (proper warm up and less acceleration during the resurfacing process).

(9) Installation of visual warning signs of the potential symptoms and hazards of $\mathrm{CO}$ and $\mathrm{NO}_{2}$ poisoning, as well as education seminars for rink staff, coaches, parents, and patrons of ice rinks of all ages.

(10) Develop a prudent emergency plan in the case of a poisoning incident.

Authors' affiliations

T W Pelham, Department of Pathology, Faculty of Medicine, Dalhousie University, Halifax, Nova Scotia, Canada

L E Holt, School of Health and Human Performance, Dalhousie University M A Moss, Department of Pathology, Dalhousie University

\section{REFERENCES}

1 André D, Kosatsky T, Bonnier J. Intoxication au monoxyde de carbone dans les arénas: problématique et moyens d'intervention. Can J Public Health 1988;79:124-9.

2 Canadian Laboratory for Disease Control. Carbon monoxide in ice arenas: British Columbia. Canada Dis Weekly Rep 1984;10-14:53-5.

3 Dewailly E, Allaire S. Nitrogen dioxide poisoning at a skating rink: Quebec. Canada Dis Weekly Rep 1988;14-15:61-2.

4 Hedberg K, Hedberg CW, lber C, et al. An outbreak of nitrogen dioxide-induced respiratory illness among ice hockey players. JAMA 1989;262:3014-17

5 Miller RK, Ryan MC, Bilows P. Carbon monoxide poisoning in indoor ice skating arenas. Virginia Medical 1989;116:74-6.

6 Centers for Disease Control. Carbon monoxide intoxication associated with use of a gasoline-powered resurfacing machine at an ice-skating rink: Pennsylvania. MMWR Morb Mortal Wkly Rep 1984;33:49-51.

7 Morgan WKC. Zamboni disease. Arch Intern Med 1995; 155:2479-80.

8 Paulozzi LJ, Satink F, Spengler RF. A carbon monoxide mass poisoning in an ice arena in Vermont. Am J Public Health 1991;81:222.

9 Roseland $M$, Bluham $G$. Health effects resulting from nitrogen dioxide exposure in an indoor ice arena. Arch Environ Health 1999;54:52-7.

10 Soparkar G, Mayers I, Edouard I, et al. Toxic effects from nitrogen dioxide in ice-skating. Can Med Assoc J 1993;148:1 181-2.

11 Saslow AR, Clark PS. Carbon monoxide poisoning report of an outbreak involving 171 persons. J Occup Med 1973;13:490-2.

12 Smith W, Anderson T, Anderson HA. Nitrogen dioxide and carbon monoxide intoxication in an indoor ice arena: Wisconsin 1992. MMWR Morb Mortal Wkly Rep 1992;41:383-5.

13 Anderson DE. Problems created for ice arenas by engine exhaust. Am Ind Hyg Assoc J 1971;32:790-801.

14 Berglund $M L$, Bralock $G$, Bylin J, et al. Personal $\mathrm{NO}_{2}$ exposure monitoring shows high exposure among ice-skating schoolchildren. Arch Environ Health 1994;49:17-24.

15 Braver M, Lee K, Spengler JD, et al. Nitrogen dioxide in indoor ice skating facilities: an international survey. J Air Waste Manag Assoc 1997;47:1095-102. 
16 Brauer M, Spengler JD. Nitrogen dioxide exposures inside ice skating rinks. Am J Public Health 1994;84:429-33.

17 Brauer M, Spengler JD, Lee K, et al. Air pollutant exposure inside ice hockey rinks: exposure assessment and reduction strategies. In: Castaidi CR, Bishop PJ, Hoerner EF, eds. Safety in ice hockey. Philadelphia: American Society for Testing and Materials, 1993;2:142-56.

18 Centers for Disease Control. Carbon monoxide exposures at an ice-skating rink: Colorado. MMWR Morb Mortal Wkly Rep 1986;35:435-7.

19 Davis BP, Drenchen A. Carbon monoxide of concern in ice arenas. J Environ Health 1979;42:120-2.

20 Hillman KE. The potential for and control of control monoxide poisoning in British Columbia ice arenas. Environmental Health Review 1984;100-8

21 Johnson CJ, Moran JC, Paine SC, et al. Abatement of toxic levels of carbon monoxide in Seattle ice-skating rinks. Am J Public Health 1975;65:1087-9.

22 Junker $\mathbf{M}$, Koller T, Monn $C$. An assessment of indoor air contaminants in buildings with recreational activity. Sci Total Environ 2000;246: 139-52.

23 Karlson-Stiber C, Hojer J, Sjoholm A, et al. Nitrogen dioxide pneumonitis in ice hockey players. J Intern Med 1996;239:451-6.

24 Kwok PW. Evaluation and control of carbon monoxide exposure in indoor skating arenas. Can J Public Health 1983;74:261-5.

25 Lee K, Yanagisawa Y, Spengler JD, et al. Carbon monoxide and nitrogen dioxide exposure in indoor ice skating rinks. J Sports $S_{c i}$ 1994; 12:279-83.

26 Levy JI, Lee K, Yanagisawa Y, et al. Determinants of nitrogen dioxide concentrations in indoor ice skating rinks. Am J Public Health 1998;88:1781-6.

27 Lévesque B, Dewailly $E$, Lavoie $R$, et al. An experiment to evaluate carbon monoxide absorption by players in ice skating rinks. Vet Hum Toxicol 1991;33:5-8

28 Lévesque B, Dewailly $\mathrm{E}$, Lavoie $\mathrm{R}$, et al. Carbon monoxide in indoor ice skating rinks: evaluation of aborption by adult hockey players. Am J Public Health 1990;80:594-8.

29 Luckhurst DG, French W. Carbon monoxide in indoor skating arenas. Can Med Assoc J 1979;121:1053-4.

30 Pennanen AS, Salonen RO, Alm S, et al. Characterization of air quality in five Finnish indoor ice arenas. J Air Waste Manag Assoc 1997;47:1079-86

31 Oatman L, Zetterlund M. Regulating air quality in ice arenas. In: Proceedings of the 5th air quality and climate conference. Ottawa: Canada Mortgage and Housing Corporation, 1990;373-7.

32 Sorensen AJ. The importance of monitoring carbon monoxide levels in indoor ice skating rinks. J Am Coll Health 1986;34:185-6.

33 Spengler JD, Stone KR, Lilley FW. High carbon monoxide levels measured in enclosed skating rinks. Journal of the Air Pollution Control Association 1978;28:776-9.

34 Department of Public Health, Commonwealth of Massachusetts. Requirements to maintain air quality in indoor skating rinks. 105CMR 675.000. State sanatary code, Chapter XI. Boston: Commonweatih of Massachusetts, 1996.

35 State of Minnesota. Minnesota rules, enclosed sports arenas. Pts 4635.1 100-4635.2000. Minneapolis: State of Minnesota, 1985.

36 Pribyl CR, Racca J. Toxic gas exposures in ice arenas. Clin J Sport Med $1996 ; 6: 232-6$

37 Régie de la sécurité dans les sports du Québec. Guide de sécurité et de prévention dans les arénas. Trois-Rivléres: Régie de la sécurité dans les sports du Québec, 1993.

38 Turino GM. Effects of carbon monoxide on the cardiorespiratory system. Carbon monoxide toxicity: physiology and biochemistry. Circulation $1981 ; 63: 253$ A-9A.

39 Duvelleray MA, Mehmel H, Blaver M. Haemoglobin-oxygen equilibrium and coronary blood flow: an analog model. J Appl Physiol 1973;35:480-4.

40 Forbes WH, Sargent F, Roughton FTW. The rate of carbon monoxide uptake by normal men. Am J Physiol 1945;4:143.

41 Ayres SM, Giunell S, Mueller H. Myocardial and systemic responses to carboxyhaemoglobin. Ann N Y Acad Sci 1970;174:268-93.

42 Koskela RS, Mutanen P, Sorsa JA, et al. Factors predictive of ischemic heart disease mortality in foundry workers exposed to carbon monoxide. Am J Epidemiol 2000;152:628-32.

43 Wickramatillake HD, Gun RT, Ryan P. Carbon monoxide exposures in Australian workplaces could precipitate myocardial ischaemia in smoking workers with coronary artery disease. Aust N Z J Public Health 1998;22:389-93.
44 Vogel JA, Gleser MA. Effects of carbon monoxide on oxygen transport during exercise. J Appl Physiol 1972;32:234-9.

45 Aronow WS, Isbell MW. Carbon monoxide effects on exercise-induced angina pectoris. Ann Intern Med 1973;79:392-5.

46 Amitai Y, Zlotogorski Z, Golan-Katzav V, et al. Neuropsychological impairment from acute low-level exposure to carbon monoxide. Arch Neurol 1998;55:845-8

47 Gale SD, Hopkins RO, Weaver LK, et al. MRI, quantitative MRI, SPECT, and neuropsychological findings carbon monoxide poisoning. Brain Inj 1999;13:229-43.

48 Pelham TW. Incidences of asthma and bronchitis in a group of young male hockey players: a pilot study. Nova Scotia Medical Journal 1993;72:21-4.

49 Pelham TW, Holt LE. Chronic obstructive pulmonary diseases and indoor ice sports. National Strength and Conditioning Association Journal (environmental considerations) 1993;15:73-4.

50 Pelham TW, Holt LE, Moss M. Chronic obstructive pulmonary diseases in young hockey players: incidences and environmental risk factors. Nova Scotia Medical Journal 1993;72:201-4.

51 Fitch KD, Morton AR. Specificity of exercise in exercise-induced asthma. BM 1971;4:577-81.

52 Larsson K, Ohlsen P, Larsson L, et al. High prevalence of asthma in cross country skiers. BM 1993;307:1326-9.

53 Dekker C, Dales R, Bartlett $S$, et al. Childhood asthma and the indoor environment. Chest 1991;100:922-6.

54 National workshop on asthma. Executive summary and recommendations, Ottawa, May 19, 1988. Chronic Dis Can $1989 ; 10: 33-4$

55 Pelham TW, Holt LE, Moss MA. Pulmonary function of children with asthma in selected indoor sport environments. Pediatric Exercise Science 1999; 11:406-13.

56 American Conference of Governmental Industrial Hygienists. TLV's threshold limit values and biological exposures indices for 1995-6. Washington: American Conference of Governmental Industrial Hygienists, 1996.

57 Ontario Recreation Facilities Association. Air alert toxic gases in community aernas. North York, Ontario: ORFA, 1987

58 Coueffin K. Carbon monoxide: a problem in enclosed ice skating aernas. Environ Health Rev 1981;33:49-96.

59 Department of National Health and Welfare: Exposure guidelines for residential indoor air quality, Ottawa, Ontario, Canada: Environmental Health Directorate, Department of National Health and Welfare, 1990. (EHD-TR-156, Cat H49-58/1990E.)

60 Baver MA, Utell M, Morrow PE, et al. Inhalation of $0.3 \mathrm{ppm}$ nitrogen dioxide potentiates exercise-induced bronchospasm in asthmatics. Am Rev Respir Dis 1986;134:1203-8.

61 Kleimman MT, Baily RM, Linn WS. Effects of 0.2 ppm nitrogen dioxide on pulmonary function and response to bronchoprovocation in asthmatics. J Toxicol Environ Health 1983;12:815-26.

62 Ahmed T, Marchette B, Danta I, et al. Effect of 0.1 ppm $\mathrm{NO}_{2}$ on bronchial reactivity in normals and subjects with bronchial asthma [abstract]. Am Rev Respir Dis 1982;125:152.

63 Hazucha MJ, Ginsberg JF, McDonnell WF, et al. Effects of 0.1 ppm nitrogen dioxide on airways of normals and asthmatics subjects. J Appl Physiol 1983:54:730-9

64 Orehek J, Massari JP, Gaynard P, et al. Effect of short term, low level nitrogen dioxide exposure on bronchial sensitivity of asthmatic patients. $J$ Clin Invest 1976;57:301-7.

65 Cleary WM. Indoor ice rinks: a public health problem. Michigan Occupational Health 1973:19:1-3.

66 Ford DP, Rothman N, Hedberg K, et al. Nitrogen dioxide-induced respiratory respiratory illness in ice hockey players. JAMA 1990;263:3024-5

67 Garcia HP. Ice skating arenas: the cold air pool. Environ Health Rev 1986;30:5-13.

68 Hampson NB. Carbon monoxide poisoning in an indoor ice aerana and bingo hall: Seattle 1996. MMWR Morb Mortal Wkly Rep 1996;62:267.

69 Ice hockey lung: $\mathrm{NO}_{2}$ poisoning. Lancet 1990;335:1191.

70 Salonen RO. Carbon monoxide poisoning during a junior ice hockey tournament. Am J Respir Crit Care Med 1994;149:A661.

71 American Society of Heating, Refrigerating, and Air-Conditioning Engineers. Ventilation for accepable air quality. Atlanta, GA: ASHRACE, 1989

72 Yang C, Demokritou P, Chen Q, et al. Experimental validation of a computational fluid dynamics model for IAQ applications in ice rink arenas. Indoor Air 2001;11:120-6. 